\title{
STUDI KONSENTRASI GULA YANG TEPAT PADA MANISAN KERING UBI JALAR UNGU (Ipomoea batatas L) TERHADAP KARAKTERISTIK YANG DIHASILKAN
}

\author{
Nurhidayah $^{(1)}$, dan Rifni Novitasari, S.Tp., MP ${ }^{(2)}$ \\ (1) Alumni Teknologi Pangan, UNISI \\ (2) Dosen Teknologi Pangan UNISI, Riau
}

\begin{abstract}
Abstrak
Penelitian dengan judul studi konsentrasi gula yang tepat pada manisan kering ubi jalar ungu (Ipomoea batatas L) terhadap karakteristik yang dihasilkan. Penelitian ini dilaksanakan di laboratorium Teknologi Pangan, Fakultas Pertanian, Universitas Islam Indragiri Tembilahan dan analisa dilaksanakan di laboratorium Teknologi Pangan, Fakultas Pertanian, Universitas Andalas Padang. Pada bulan Mei - Juli 2017. Tujuan yang ingin dicapai pada penelitian ini adalah untuk mengetahui konsentrasi gula yang tepat pada manisan kering yang dihasilkan. Penelitian yang telah dilakukan dengan rancangan acak lengkap (RAL) dengan perlakuan yaitu konsentrasi gula perberat bahan, yang terdiri dari empat perlakuan, yaitu A : 40\%, B : 50\%, C : 60\%, dan D : 70\%. Hasil penelitian ubi jalar ungu berdasarkan uji kimia dan uji organoleptik, perlakuan terbaik manisan kering ubi jalar ungu yaitu perlakuan D (konsentrasi gula 70\%) dengan kadar air 5,00\% kadar gula 21,00\% kadar pati $29,66 \%$ nilai aroma 3.40 , warna 3.45 , tekstur 3.30 dan rasa 3.40 .
\end{abstract}

Kata Kunci : manisan, ubi jalar ungu, konsentrasi gula

\section{PENDAHULUAN}

Tanaman ubi jalar merupakan jenis tanaman yang tergolong kedalam jenis tanaman merambat atau menjalar berupa semak yang berasal dari Amerika tengah dan tahun 1960 masuk ke Indonesia. Berdasarkan jumlah total produksi ubi jalar di dunia, Indonesia merupakan negara penghasil kedua terbesar setelah Cina. Sekitar $98 \%$ pertanian ubi jalar dunia berada dinegara-negara berkembang dengan distribusi : cina $80 \%$, negara-negara asia lainnya $6 \%$, Afrika 5\% dan Ameriak Latin 2\%. Dan berdasarkan data Badan Pusat Statistik di Provinsi Riau produksi Ubi jalar dari tahun 1993 - 2015 berkisar 82,75 Kwintal/Ha (BPS 2015).

Ditinjau dari potensi sumber daya, wilayah Indonesia memiliki potensi ketersediaan pangan sebagai sumber karbohidrat yang cukup besar. Salah satu sumber karbohidrat adalah jenis umbi-umbian seperti ubi jalar (Ipomoea batatas L). Ketika dipanen ubi jalar mengandung $16-40 \%$ bahan kering. Dari jumlah tersebut $75-90 \%$ adalah karbohidrat yang mengandung pati, gula, selulosa, hemiselulosa dan pektin. Selama pemasakan ubi jalar maka sebagian pati diubah menjadi gula yaitu maltosa dan dekstrosa, jenis gula 
lain yang terdapat didalam ubu jalar yang telah masak adalah fruktosa, glukosa dan rafinosa. Selain ubi jalar berdaging putih dan merah yang sudah umum dimanfaatkan, pada saat ini telah banyak pula dilakukan pengolahan ubi jalar berdaging ungu, terutama sebagai makanan fungsional karena kandungan antioksidannya yang tinggi (Koswara, 2013).

Ubi jalar ungu merupakan sumber antosianin, senyawa antosianin berfungsi sebagai antioksidan dan penangkap radikal bebas, sehingga berperan untuk mencegah terjadi penuaan, kanker, dan penyakit degeneratif. Selain itu, antosianin juga memiliki kemampuan sebagai antimutagenik dan antikarsinogenik, mencegah gangguan fungsi hati, antihipertensi, dan menurunkan kadar gula darah (Jusuf, (2005) citt Elhusana, (2013)).

Ubi jalar pada umumnya terbagi atas 3 yaitu ubi putih, ubi kuning atau orange dan ubi ungu. Menurut data penelitian ubi ungu mengandung lisin, $\mathrm{Cu}, \mathrm{Mg}, \mathrm{K}, \mathrm{Zn}$ rata-rata $20 \%$ dan sumber kalori yang cukup tinggi. Ditambah vitamin A, Vitamin C dan Vitamin B (Wahidah,2016). Ubi jalar ungu dapat dimanfaatkan dalam bentuk segar, selain dikukus atau digoreng juga sesuai untuk bahan baku keripik, kubus/granula instan, beragam kue jajanan/basah, serta selai. Selain itu ubi jalar ungu juga dapat diolah menjadi awetan berupa manisan kering. Dengan warna ungu yang alami tentu akan memberikan hasil yang lebih menarik tanpa harus menggunakan pewarna buatan

Manisan merupakan salah satu bentuk makanan olahan yang banyak disukai oleh masyarakat. Dalam pembuatan manisan menggunakan gula, dengan cara merendam dan memanaskan buah dalam madu. Konsentrasi gula yang cukup tinggi $(70 \%)$ sudah dapat menghambat pertumbuhan mikroba, akan tetapi pada umumnya gula dipergunakan dengan salah satu teknik pengawetan lainnya misalnya dikombinasikan dengan keasaman yang rendah, pasteurisasi, penyimpanan pada suhu rendah, pengeringan, pembekuan dan penambahan bahan kimia seperti $\mathrm{SO} 2$, asam benzoat dan lain-lain (Kusmiadi, 2003).

Hasil penelitian Amalia (2015) pada manisan kering kelapa diperoleh hasil terbaik yaitu kadar sukrosa tertinggi $47.130 \%$ dengan konsentrasi gula $65 \%$. Kadar lemak terendah $6.95 \%$ dengan konsentrasi gula $65 \%$ kadar air terendah adalah $14.58 \%$ konsentrasi gula $55 \%$. Berdasarkan uji organoleptik manisan kering kelapa yang disukai panelis adalah manisan kering kelapa dengan konsentrasi gula $70 \%$ dengan nilai warna 4.15 , aroma 3.55 , tekstur 3.99 dan rasa 4.05. Penambahan gula pasir dalam pembuatan manisan merupakan salah satu faktor yang perlu diperhatikan. Disamping untuk menambah cita rasa juga untuk menghambat terjadinya perubahan warna, mengurangi laju difusi oksigen terlarut dan menurunkan kadar tanin (Santoso,1998). Dalam pembuatan manisan kering ubi ungu perlu adanya penambahan gula yang tepat agar diperoleh keseimbangan komposisi bahan pembuatan terutama dosis gula

\subsection{Rumusan Masalah}

Berdasarkan prapenelitian yang dilakukan dengan konsentrasi gula $40 \%$ $50 \% 60 \%$ dan $70 \%$ rata - rata manisan kering yang dihasilkan bagus yang dilihat secara fisik dari segi warna, rasa, aroma dan tekstur. Namun secara kimia belum diketahui hasil yang terbaik.

Berdasarkan uraian diatas penulis ingin melakukan penelitian mengenai ubi jalar ungu sebagai bahan utama 
dalam pembuatan manisan kering dengan penambahan gula sukrosa sebagai bahan pemanis. Tetapi belum diketahui berapa persentase yang tepat dalam penambahan gula sukrosa agar menghasilkan manisan yang memiliki rasa, tekstur, warna yang disukai panelis serta sesuai standar. Maka dari itu akan dilakukan penelitian mengenai "Studi Konsentrasi Gula Yang Tepat Pada Manisan Kering Ubi Jalar Ungu Terhadap Karakteristik Yang Dihasilkan"

\section{Tujuan Penelitian}

Tujuan dari penelitian ini adalah untuk mengetahui perlakuan gula yang tepat untuk menghasilkan manisan kering ubi ungu yang baik dari segi kualitas serta analisa kimia dan organoleptik.

\section{Manfaat Penelitian}

Manfaat dari penelitian ini adalah :

1. Memberikan informasi kepada masyarakat akan olahan ubi ungu yang belum banyak dimanfaatkan menjadi olahan awetan yang bermanfaat serta memberikan nilai ekonomi yang tinggi

2. Terciptanya produk baru

\section{METODOLOGI PENELITIAN}

\section{Bahan}

Bahan yang digunakan di dalam penelitian ini adalah ubi ungu, air, gula pasir putih bersih (sukrosa) dan kapur sirih. Adapun bahan yang digunakan untuk analisa gula reduksi adalah : aquades, pb asetat, NA-Oksalat, Nahidrat, larutan luffchoorl $(\mathrm{Kl}), \mathrm{H}_{2} \mathrm{SO}_{4}$, dan Na-Thiosulfit.

\section{Alat}

Alat yang digunakan di dalam penelitian ini adalah timbangan analitik, pisau, baskom, kompor, toples, panci. Adapun alat yang digunakan untuk analisa kimia pengujian gula reduksi adalah : timbangan, labu takar, erlenmeyer, dan inkubator.

\section{Metode Penelitian}

Rancangan percobaan yang digunakan di dalam penelitian ini adalah rancangan acak lengkap (RAL) dengan perlakuan konsentrasi gula terdiri dari empat perlakuan yaitu :

$A=40 \%$ gula pasir / berat bahan

$\mathrm{B}=50 \%$ gula pasir / berat bahan

$\mathrm{C}=60 \%$ gula pasir / berat bahan

$\mathrm{D}=70 \%$ gula pasir / berat bahan

Perlakuan ini diulang sebanyak 3 kali sehingga diperoleh pola perlakuan $4 \times 3$ dengan jumlah 12 satuan unit percobaan.

\section{Pelaksanaan Penelitian}

\section{Pembuatan Manisan Kering Ubi Jalar Ungu (Ipomoea Batatas)}

Proses pembuatan manisan kering ubi ungu hampir sama dengan pembuatan manisan pada umumnya. Prosedur kerja didalam penelitian beracu pada penelitian Suryani (2016) yang sudah dimodifikasi yaitu :

\section{Sortasi}

Sortasi (pemilihan) dilakukan untuk memilih ubi ungu yang layak untuk digunakan. Ubi ungu yang dipilih adalah ubi yang memiliki ciri fisik yaitu kulitnya berwarna ungu, keras dan tidak berlubang ataupun cacat.

2. Pengupasan

Pengupasan ubi ungu bertujuan untuk memisahkan antara kulit dengan 
daging buah. Pengupasan dapat dilakukan dengan cara sederhana dengan menggunakan pisau.

3. Pencucian

Pencucian dengan air bersih bertujuan untuk membersihkan daging buah ubi jalar ungu dari kotoran yang menempel dan getah.

4. Pengirisan

Pengirisan bertujuan untuk memperkecil ukuran daging ubi ungu sehingga mempercepat peresapan gula kedalam daging buah ubi ungu dam membentuk daging buah ubi ungu lebih menarik. Pengirisan daging buah ubi ungu dalam pengolahan manisan adalah berbentuk bulat dengan ketebalan $0,5 \mathrm{~cm}$.

5. Pencucian

Pencucian dengan air bersih untuk membersihkan kotoran dan getahgetah yang menempel pada daging ubi ungu yang masih menempel.

6. Perendaman dalam larutan kapur

Perendaman dalam larutan air $500 \mathrm{ml}$ dan kapur 10 gr bertujuan untuk memperkuat tekstur daging buah ubi ungu, menghilangkan getah pada bahan baku. Lamanya perendaman dapat berlangsung selama 60 menit.

7. Pencucian

Potongan-potongan daging buah ubi ungu yang telah direndam diangkat dari perendaman lalu ditiriskan, setelah ditiriskan lalu dicuci pada air yang mengalir hungga bersih. Tujuan pencucian ini adalah untuk menghilangkan rasa dari pada kapur.

8. Pemasakan

Pada saat pemasakan terlabih dahulu pembuatan larutan gula dibuat sesuai perlakuan yaitu : $(\mathrm{A}=40 \% \mathrm{bb}, \mathrm{B}=$
$50 \% \mathrm{bb}, \mathrm{C}=60 \% \mathrm{bb}, \mathrm{D}=70 \% \mathrm{bb})$ dengan penambahan air sebanyak 300 $\mathrm{ml}$ setiap perlakuan dengan berat bahan 250 gr. Larutan gula dimasak dengan suhu $80^{\circ} \mathrm{C}$ sampai larutan mencair dan masukkan irisan ubi ungu yang telah di timbang. Lakukan pemasakan hingga larutan kering dengan waktu selama 30 menit

\section{Pengeringan}

Manisan yang telah masak di keringkan menggunakan sinar matahari selama 3 hari dengan selang waktu 8 jam perharinya.

\section{Pengamatan}

Pada penelitian ini dilakukan pengamatan untuk mengukur kadar air, kadar gula reduksi, kadar pati, dan organoleptik.

\section{HASIL DAN PEMBAHASAN}

\subsection{Kadar Air Manisan Kering Ubi Jalar}

Ungu

Kandungan air dalam bahan pangan ikut menentukan tingkat penerimaan, kesegaran dan daya awet produk tersebut. Sebagian besar dari perubahan-perubahan kimia dan biokimia pada bahan makanan terjadi dalam media air yang berasal dari bahan itu (Winarno, 2008).

Hasil analisa sidik ragam menunjukkan bahwa konsentrasi gula memberikan pengaruh yang berbeda nyata terhadap kadar air manisan kering ubi ungu yang dihasilkan. Rata-rata kadar air berdasarkan perlakuan konsentrasi gula dapat dilihat pada tabel 1 . 
Tabel 1. Rata-Rata Kadar Air Manisan Kering Ubi Ungu Berdasarkan Perlakuan Kadar Gula

\begin{tabular}{|c|c|}
\hline Perlakuan & Kadar Air \% \\
\hline $\mathrm{D}=$ Konsentrasi Gula $(70 \%)$ & $5,00 \quad \mathrm{~A}$ \\
\hline $\mathrm{C}=$ Konsentrasi Gula $(60 \%)$ & 6,33 \\
\hline $\mathrm{B}=$ Konsentrasi Gula $(50 \%)$ & 7,66 \\
\hline $\mathrm{A}=$ Konsentrasi Gula $(40 \%)$ & 9,66 \\
\hline
\end{tabular}

Keterangan: angka-angka pada jalur yang sama diikuti oleh huruf yang sama menunjukkan berbeda tidak nyata menurut Uji Beda Nyata Terkecil pada taraf 5\%.

Tabel 1 memperlihatkan bahwa kadar air manisan kering ubi ungu dengan perlakuan konsentrasi gula berkisar antara 5,00\% - 9,66\%. Dimana kadar air tertinggi terdapat pada perlakuan A (40\% konsentrasi gula) yaitu 9,66 \% dan kadar air terendah terdapat pada perlakuan D (konsentrasi gula $70 \%$ ) yaitu $5,00 \%$. Dari analisa tersebut kadar air untuk keseluruhan manisan kering ubi ungu dengan perlakuan $\mathrm{A}, \mathrm{B}, \mathrm{C}$, dan $\mathrm{D}$ yaitu dengan perlakuan gula $40 \%, 50 \%, 60 \%$, dan $70 \%$ masih memenuhi Standar Nasional Indonesia (SNI) yaitu maksimal $25 \%$.

Hasil uji lanjut menunjukkan bahwa perlakuan A, B, C dan D berbeda nyata. Hal ini menunjukkan bahwa konsentrasi gula yang berbeda memberikan pengaruh yang berbeda nyata terhadap kadar air yang dihasilkan setiap perlakuan. Hal ini menunjukkan bahwa semakin tinggi konsentrasi gula yang ditambahkan pada pembuatan manisan kering ubi ungu maka kadar air yang dihasilkan akan semakin rendah dan sebaliknya semakin rendah konsentrasi gula yang ditambahkan maka semakin tinggi kadar air yang dihasilkan. Hal ini disebabkan karena gula yang ditambahkan akan menyebabakan air keluar dari daging ubi ungu pada saat pengolahan dan larutan gula masuk kedalam daging ubi ungu menggantikan sel yang lainnya yang mengalami difusi. Hal ini juga sesuai dengan pendapat (Nugraha, 2015) yang menyatakan bahwa penurunan kadar air disebabkan karena apabila gula ditambahkan kedalam bahan pangan dalam konsentrasi paling sedikit $40 \%$, maka sebagian air yang ada terikat oleh gula. Kemampuan gula untuk mengikat air itulah yang menyebabkan gula dapat sebagai pengawet.

Menurut Buntaran, dkk (2009) ubi jalar ungu yang direndam dalam larutan gula akan mengalami tekanan osmosis yaitu tekanan molekul-molekul gula pada dinding sel buah sampai larutan gula masuk kedalamnya, akibatnya air yang berada dalam sel buah keluar. Gula (sukrosa) memiliki sifat higroskopis, artinya memiliki kemampuan dalam mengikat air (Kartika dan Fitrri, 2015). Selain itu dengan adanya proses pemanasan maka air akan menguap, sehingga kadar air akan berkurang. Hal ini juga sesuai dengan pendapat Apriyanto (2000), bahwa pemansaan akan menguapkan air sehingga air pada bahan akan berkurang.

\section{Kadar Gula Reduksi Manisan Kering Ubi Ungu}

Hasil analisa sidik ragam menunjukkan bahwa konsentrasi gula memberikan pengaruh yang berbeda nyata terhadap gula reduksi manisan kering ubi ungu yang dihasilkan. Ratarata kadar gula reduksi berdasarkan perlakuan konsentrasi gula dapat dilihat pada tabel 2. 
Tabel 2. Rata-Rata Kadar Gula Reduksi Manisan Kering Ubi Ungu Berdasarkan Perlakuan Kadar Gula.

\begin{tabular}{|l|l|}
\hline \multicolumn{1}{|c|}{ Perlakuan } & Kadar gula \% \\
\hline $\mathrm{A}=$ Konsentrasi Gula (40\%) & $18,33 \mathrm{~A}$ \\
\hline $\mathrm{B}=$ Konsentrasi Gula (50\%) & $19,66 \quad \mathrm{~A}$ \\
\hline $\mathrm{C}=$ Konsentrasi Gula (60\%) & $20,66 \mathrm{AB}$ \\
\hline $\mathrm{D}=$ Konsentrasi Gula (70\%) & $21,00 \mathrm{~B}$ \\
\hline
\end{tabular}

Keterangan: angka-angka pada jalur yang sama diikuti oleh huruf yang sama menunjukkan berbeda tidak nyata menurut Uji Beda Nyata Terkecil pada taraf 5\%.

Tabel 2 memperlihatkan bahwa kadar gula reduksi manisan kering ubi ungu dengan perlakuan konsentrasi gula berkisar antara $18,33 \%-21,00 \%$. Kadar gula reduksi tertinggi terdapat pada perlakuan D $(70 \%$ konsentrasi gula) yaitu 21,00 dan kadar gula reduksi terdapat pada perlakuan A (40\% konsentrasi gula) yaitu $18,33 \%$. Secara keseluruhan kadar gula reduksi yang terkandung oleh manisan kering ubi ungu dengan perlakuan $\mathrm{A}, \mathrm{B}, \mathrm{C}$ dan $\mathrm{D}$ dengan perlakuan konsentrasi gula $40 \%$, $50 \%$, 60\% dan $70 \%$ belum memenuhi Standar Nasional Indonesia (SNI) yaitu minimum $40 \%$.

Hasil uji lanjut menunjukkan bahwa perlakuan D dengan konsentrasi gula $70 \%$ memberikan pengaruh yang berbeda nyata. Hal ini dikarenakan gula yang ditambahkan selama proses pemanasan sebagian gula terurai menjadi glukosa dan fruktosa. Sifat ini menunjukkan semakin banyak gula yang ditambahkan maka kadar gula yang dihasilkan juga semakin meningkat. Hal ini sesuai dengan pendapat winarno (2008), bahwa pada larutan gula yang tinggi akan menyebabkan total gula meningkat.

Salah satu fungsi sukrosa adalah memberikan rasa manis pada produk, sehingga pada saat ditambahkan pada produk dengan penambahan yang tinggi, dapat memberikan tingkat kemanisan yang tinggi pada produk tersebut. Tingginya kadar sukrosa yang terdapat pada manisan menyebabkan produk manisan lebih lama disimpan. Tujuan pemberian gula pada manisan selain memberikan rasa manis, gula juga bersifat sebagai pengawet karena mampu mengikat air bebas yang ada sehingga tidak dapat digunakan oleh mikroba pembusuk (Kartika dkk 2015).

\section{Kadar Pati Manisan Kering Ubi Ungu}

Hasil analisa sidik ragam menunjukkan bahwa konsentrasi gula memberikan pengaruh yang berbeda nyata terhadap kadar pati manisan kering ubi ungu yang dihasilkan. Ratarata kadar gula reduksi berdasarkan perlakuan konsentrasi gula dapat dilihat pada tabel 3.

Tabel 3. Rata-Rata Kadar Pati Manisan Kering Ubi Ungu Berdasarkan Perlakuan kon Gula.

\begin{tabular}{|c|c|}
\hline Perlakuan & Kadar Karbohidrat \% \\
\hline $\mathrm{D}=$ Konsentrasi Gula (70\%) & $23,66 \quad \mathrm{~A}$ \\
\hline $\mathrm{C}=$ Konsentrasi Gula (60\%) & $26,66 \quad \mathrm{AB}$ \\
\hline $\mathrm{B}=$ Konsentrasi Gula (50\%) & $27,66 \quad \mathrm{BC}$ \\
\hline $\mathrm{A}=$ Konsentrasi Gula (40\%) & $29,66 \quad \mathrm{C}$ \\
\hline
\end{tabular}

Keterangan: angka-angka pada jalur yang sama diikuti oleh huruf yang sama menunjukkan berbeda tidak nyata menurut Uji Beda Nyata Terkecil pada taraf 5\%. 
Tabel 3 menunjukkan bahwa kadar pati manisan kering ubi ungu dengan perlakuan konsentrasi gula berkisar antara 23,66\% - 29,66\%. Kadar pati terendah terdapat pada perlakuan D dengan konsentrasi gula $70 \%$ yaitu 23,66\%. Untuk kadar pati tertinggi terdapat paa perlakuan A dengan konsentrasi gula $40 \%$ yaitu $29,66 \%$. Secara keseluruhan kadar pati yang terkandung oleh manisan kering ubi ungu dengan perlakuan $\mathrm{A}, \mathrm{B}, \mathrm{C}$ dan $\mathrm{D}$ dengan perlakuan konsentrasi gula $40 \%$, $50 \%, 60 \%$ dan $70 \%$ masih mengandung kadar pati meskipun tidak sebanyak ubi ungu sebelum diolah.

Tingginya kadar pati pada perlakuan A dikarena rendahnya konsentrasi gula yang diberikan sehingga interaksi antara gula dan air stabil. Sedangkan penurunan kadar pati pada perlakuan D dikarena konsentrasi gula yang tinggi sehingga terjadi proses karamelisasi yang menyebabkan berkurangnya kadar pati pada manisan kering yang dihasilkan. Hal lain juga karena adanya interaksi antara pati, gula dan proses pemanasan. Dimana Sebagian besar pati mengandung Amilosa antara 15-35\%. Dalam butiran pati ramtairantai amilosa dan amilopektin tersusun dalam bentuk semi kristal, yang menyababkan tidak larut dalam air. Namun bila dipanaskan dengan air struktur kristal akan rusak. Proses pemasakan pati disamping dapat membentuk gel juga dapat memecah sel, dimana dalam proses pencernaan semua bentuk pati dihidrolisa menjadi glukosa (Almatsie, 2004 cit Wakul, 2014).

\section{Uji organoleptik}

\section{Aroma}

Uji organoleptik pada aroma dilakukan untuk mengetahui aroma mana yang paling disukai oleh panelis dari tiap-tiap perlakuan. Berdasarkan hasil penelitian menunjukkan bahwa perlakuan penambahan gula memberikan pengaruh berbeda tidak nyata terhadap aroma manisan kering yang dihasilkan, dimana $F_{\text {hitung }}(1,68)<$ $F_{\text {tabel }}(2,76)$.

Nilai rata-rata manisan kering ubi jalar ungu berkisar antara 3,85 - 3,35. Dimana aroma yang disukai panelis pada perlakuan $\mathrm{C}$ dengan konsentrasi gula $60 \%$ yaitu 3,85 dan skor terendah pada perlakuan D yaitu dengan konsentrasi gula $70 \%$.

Berdasarkan hasil analisis sidik ragam terhadap aroma manisan kering ubi jalar ungu, perlakuan yang diberikan tidak berpengaruh terhadap aroma manisan ubi jalar ungu. Hal ini karenakan ubi jalar ungu bukanlah termasuk buah yang memiliki aroma yang kuat, ditambah lagi dengan adanya tahap pengeringan sehingga menghasilkan aroma yang sama pada setiap perlakuan yang diberikan, sehingga para panelis memberikan nilai tidak lebih dari 3 yaitu netral.

Menurut winarno (2002) aroma biasanya timbul akibat dari adanya campuran beberapa ataupun banyak dari berbagai senyawa yang berbau. Efek gabungan menciptakan kesan yang dapat sangat berbeda dengan aroma komponen satu-persatu. Banyak aroma, rasa makanan baik alami maupun yang buatan bersifat gabungan.

\section{Rasa}

Uji organoleptik pada rasa bertujuan untuk mengetahui rasa terbaik yang disukai oleh panelis, rasa timbul akibat adanya rangsangan kimiawi yang dapat diterima oleh indra pencicip atau lidah. Rasa adalah faktor yang mempengaruhi penerimaan produk pangan. Hasil analisa sidik ragam menunjukkan bahwa manisan kering ubi 
ungu dengan konsentrasi gula yang bebeda memberikan pengarung yang berbeda nyata terhadap rasa yang dihasilkan.

Hasil uji organolptik memperlihatkan bahwa nilai rata-rata manisan kering ubi ungu terhadap rasa berkisar antara $3,40 \%$ - 4,15\%. Dimana perlakuan C dengan konsentrasi gula $60 \%$ mendapatkan skor tertinggi dengan nilai $4,15 \%$ dan perlakuan D mendapatkan skor terendah dengan konsentrasi gula $70 \%$ dengan nilai 3,40. Rata-rata panelis netral terhadap rasa manisan kering ubi ungu yang dihasilkan.

Hasil uji lanjut menunjukkan bahwa penambahan gula $60 \%$ (C) memberikan pengaruh yang berbeda nyata terhadap rasa manisan kering ubi jalar ungu. Manisan keing ubi jalar ungu dengan konsentrasi gula 60\% merupakan produk yang disukai panelis. Hal ini di duga karena kombinasi dari rasa ubi jalar ungu dengan gula yang ditambahkan memberikan rasa yang pas untuk manisan kering ubi jalar ungu sehingga disukai panelis.

Semakin tinggi penambahan gula maka rasa semakin manis, peningkatan rasa manis disebabkan karena semakin tinggi konsentrasi gula menyebabkan glukosa dan fruktosa yang dihasilkan dari inversi sukrosa juga meningkat. Perbedaan rasa manis disebabkan oleh penggunaan ubi jalar ungu pada proses pembuatan manisan kering ubi ungu. Hal ini dikarenakan pada ubi jalar ungu mengandung senyawa gula yang memberikan efek manis. Hal ini sesuai dengan pendapat Onggo (2006), perubahan pati menjadi gula selama penyimpanan menentukan rasa dari ubi dan sifat kecernaannya. Glukosa, sukrosa, dan fruktosa merupakan gulagula utama dari perombakan pati, komposisi gula tersebut berpengaruh terhadap rasa.

\section{Warna}

Uji organoleptik pada warna dilakukan untuk mengetahui warna mana yang disukai oleh panelis dari tiap tiap perlakuan dan warna yang tidak disukai panelis karena kurang menarik. Hasil penelitian menunjukkan bahwa konsentrasi gula memberikan pengaruh berbeda nyata terhadap warna manian kering ubi ungu yang dihasilkan

Hasil uji organoleptik menunjukkan bahwa nilai rata-rata manisan kering ubi ungu berkisar antara $3,45-4,30$. Dimana warna yang paling disukai panelis pada perlakuan $\mathrm{C}$ dengan konsentrasi gula $60 \%$ dengan skor 4,30 . Dan skor terendah pada perlakuan D yaitu 3,45 dengan konsentrasi gula $70 \%$.

Hasil uji lanjut menunjukkan bahwa perlakuan yang diberikan tidak pengaruh terhadap perlakuan $\mathrm{A}, \mathrm{B}$ dan D. Namun berpengaruh terhadap perlakuan $\mathrm{C}$ dengan konsentrasi gula $60 \%$. Tingginya konsentrasi gula yang diberikan pada manisan kering ubi jalar ungu, maka warna manisan semakin kecoklatan dan disukai panelis. Hal ini disebabkan karena pembentukan warna pada produk manisan kering ubi jalar ungu dipengaruhi oleh gula. Penambahan gula juga dapat menjadi faktor terjadinya perubahan warna selama proses pengeringan. Hal ini juga sesuai dengan pendapat (Triyono, 2008) Gula sukrosa merupakan bagian utama dari total padatan pada buah, sangat sensitif terhadap panas dan dapat menyebabkan warna gelap bila pemanasan terlalu lama, hal ini disebabkan oleh proses karamelisasi yang berpengaruh terhadap warna. Karamelisasi merupakan reaksi perubahan yang terjadi pada senyawa polihidroksi karbonil seperti gula-gula pereduksi. 


\section{Tekstur}

Tekstur merupakan sensasi tekanan yang dapat diamati dengan mulut (pada waktu digigit, dikunyah dan ditelan) ataupun perabaan dengan jari. Hasil analisa sidik ragam menunjukkan bahwa manisan kering ubi ungu dengan konsentrasi yang bebeda tidak memberikan pengarung yang berbeda nyata terhadap tektur yang dihasilkan.

Hasil uji organoleptik memperlihatkan bahwa nilai rata-rata manisan kering ubi ungu terhadap tekstur berkisar antara 4,05 - 3,10. Dimana perlakuan $\mathrm{C}$ dengan konsentrasi gula $60 \%$ mendapatkan skor tertinggi yaitu 4,05. Dan perlakuan A dengan konsentrasi gula $40 \%$ mendapatkan skor terendah yaitu 3,10. Rata-rata panelis menyukai tekstur yang keras.

Nilai tekstur tertinggi menunjukkan bahwa bahan tersebut memiliki tekstur keras, sedangkan nilai tekstur terendah memiliki tekstur yang tidak terlalu keras. Nilai rata-rata analisis tekstur pada tabel 10 terlihat bahwa yang memiliki tekstur terbaik adalah penambahan gula $60 \%$ (C) dengan nilai $4,05 \%$. Hal ini dikarenakan selain perendaman dengan air kapur, penambahan gula yang tinggi juga dapat mempengaruhi tekstur dari manisan kering ubi jalar ungu. Dikarenakan sifat dari gula apabila air diuapkan dari larutan gula maka gula akan mengkristal. Hal ini akan berdampak pada sifat fisik produk yaitu produk akan menjadi keras. Selain itu kadar air manisan kering ubi jalar ungu juga mempengaruhi tekstur dari manisan kering ubi jalar ungu. Manisan kering dengan penambahan gula $60 \%$ memiliki tekstur yang keras karena memiliki kadar air yang rendah (Pottre dan Hotchkist (1995) cit Finarsih (2016)).

Rendahnya tingkat penerimaan panelis terhadap perlakuan A dengan konsentrasi gula $40 \%$ disebabkan karena manisan kering yang dihasilkan kurang kering. Konsentrasi gula dapat mempengaruhi tekstur manisan kering dikarenakan pada saat ubi ungu direndam dalam larutan gula panas (proses pembuatan manisan) dengan kosentrasi tinggi akan menyebabkan air keluar dari dinding sel buah lebih cepat dari masuknya larutan gula kedalam ubi. Oleh karena iu saat pengeringan, jumlah gula dalam buah tidak mencukupi untuk mempertahankan bentuk dan tekstur buah akibat menguapnya air. Sulisna (2002) menyatakan bahwa pemanasan pada produk buah-buahan dapat meningkatkan kekerasan karena pemanasan dapat mengurangi ikatan pada molekul pektin dan membuatnya lebih kuat, terutama pada ikatan silang.

\section{KESIMPULAN DAN SARAN}

\section{Kesimpulan}

Kesimpulan yang diperoleh setelah melakukan penelitian ini adalah sebagai berikut :

1. Berdasarkan analisa kimia, diperoleh kadar air terendah 5,00 \% pada perlakuan D yaitu konsentrasi gula $70 \%$, kadar gula tertinggi yaitu 21,00 pada perlakuan D dengan konsentrasi gula $70 \%$, dan kadar pati tertinggi yaitu 29,66 \% pada perlakuan A dengan konsentrsi gula $40 \%$

2. Berdasarkan uji organoleptik, manisan kering ubi ungu yang disukai panelis adalah manisan kering ubi ungu yaitu perlakuan $\mathrm{C}$ dengan konsentrasi gula 60 dengan nilai aroma 3,85, warna 4,30, tekstur $4,05 \%$ dan rasa 4,15 .

3. Hasil terbaik manisan kering ubi ungu yaitu perlakuan D (konsentrasi gula 70\%) dengan kadar air 5,00\%, kadar gula $21,00 \%$, kadar pati $29,66 \%$, nilai 
aroma 3.40 , warna 3.45 , tekstur 3.30 . dan rasa 3.40.

\section{Saran}

Untuk penelitian selanjutnya, hendaknya dilakukan upaya menentukan daya simpan dan mengembangkan lagi produk lain dari ubi jalar ungu.

\section{DAFTAR PUSTAKA}

[AOAC]. Asseocation Of Official Analitical Chermis. 2005. Official Method Of Analysis (18 Edn). Assoacation Of Official Analytical Chermist Inc. Mayland. USA.

[AOAC]. 1995. Official Methods Of Analysis of The Association Of Analytical Chemists, Mashington D. C.

Amalia, L. 2015. Pengaruh Konsentrasi Gula Terhadap Mutu Manisan Kering Kelapa (Cocos Nucifera) [Skripsi]. Program Studi Teknologi Pangan. Fakultas Pertanian. Universitas Islam Indragiri. Tembilahan. Riau

Ariawan, Agus. 2012. Makalah Manisan. http://gusariawan.blogspot.com diakses pada tanggal 14 Februari 2017.

Apriyanto, T. 2000. Panduan Praktikum Pembuatan Manisan, Spesialis Industri Kecil Pengolahan Pangan. Dirjen Industri Kecil. Departemen Pertanian. Jakarta

Autumn. 2009. Ubi Jalar Sweet Potato (Ipomoea Batatas L). http://Autumn's.blogspot.com.

Diakses pada tanggal (20 Maret 2017)

Buntaran, W.,Astirin,OP.,Mahajouno, E. 2011. Pengaruh Konsentrasi Gula Terhadap Karakteristik Manisan Kering Tomat (Lycopeium Esculentum). Jurnal:Bioteknologi. UNS.Solo
Buntaran, B,. O. P. Astirin, E. Mahajoeno. 2009. Effect of Sugar Solution Characteristics of Dried Candy Tomato (Lycopersicum esculentum). Nusantara Bioscience Vol.2, No 2 pp 55-61

Bucle, K.A, Edwards, G.A. Fleet, Wootton, M. 1987. Ilmu Pangan. Terjemahan Purnomo, $\mathrm{H}$ dan Aidono . UI Press, Jakarta.

Depitasari K.2011. Manisan. http://Depiekristiani.blogspot.com/ Manisan/jumat/21/Oktober/2011 diakses pada tanggal [9 Februari 2017]

Fatah, M.,A., Bachtiar, Y. 2004. Membuat Aneka Manisan Buah. Agromedia Pustaka. Jakarta.

Franisa, R. 2013. Air Dalam Bahan Pangan.

http://Risnafranisa.blogspot.com/ki mia

/pangan/Air/Dalam/Bahan/Pangan/ 2/Februari/2013 diakses pada tanggal [6 Maret 2017]

Ganis, A. 2016. 14 Manfaat Ubi Ungu Bagi Kesehatan. http://Atangganis.blogspot.com/Ke sehatanBlog/14/Manfaat/Ubi/Ungu /Bagi/Kesehatan/21/Juni/2016 diakses pada tanggal [30 Maret 2017]

Hardoko, L. Hendarto, dan T. Marsillam Siregar. 2010. Pemanfaatan Ubi Jalar Ungu (Ipomea batatas L. Poir) Sebagai Pengganti Sebagian Tepung Terigu Dan Sumber Antioksidan Pada Roti Tawar. Jurnal Teknolodi dan Industri Pangan. Vol. XXI No. 1

Liur, A. F. Musfiroh, M. Mailoa, R. Bremeer, V. P. Bintoro, Kusrahayu. 2013. Potensi Penerapan Tepung Ubi Jalar Dalam Pembuatan Bakso Sapi. Fakultas Peternakan dan Pertanian. Universitas Ponegoro, Semarang. 
Lingga P. 1995. Bertanam UmbiUmbian . PT. Penebar Swadaya Jakarta.

Kartika P.N dan Fithri C.N. 2015. Studi Pembuatan Osmodehidrat Buah Nanas (Ananas Comosus L. Merr): Kajian Konsentrasi Gula Dalam Larutan Osmosis Dan Lama Perendaman. Jurnal Pangan dan Agroindustri Vol. 3 No 4 p. 1345 1355.

Karunia. D. 2013. Zat Pewarna Makanan.

http://Dindakarunia.blogspot.com/ Zat/Pewarna/Makanan/23/mei/201

4 diakses pada tanggal [01 Juni 2017]

Koswara,S. 2013. Teknologi Pengolahan Umbi-Umbian. Modul. Reserch and Community Service Institution Bogor Agricultur University.

Kumalaningsih, S. 2007.Anti Okasidan Alami. Penerbit Trubus Agrisarana. Surabaya.

Kusmiadi. 2003. Manisan Buah. Http://www.ubb.ac.id/artikel_pdf.p hp nomor urut_artikel=44. Diakses tanggal 03 Juni 2017.

Muhammad, A. 2012. Onde-Onde Ubi Ungu "Si Ungu" Yang Bergizi. http://AntariksaMuhammad.blogps ot.com/blogantariksaMuhammada kababibank/onde/onde/ubi/ungu/si/ ungu/yang/bergizi/4/februari/2012 diakses pada tanggal [30 Maret 2017]

Murniati. 2004. Teknologi Tepat Guna di Bidang Pertanian dan Industri Kecil. Badan penelitian pengembangan (BPP) Provinsi Sumtra Utara. Medan

Nugraha,S.T. 2015. Penggulaan Manisan Buah dan Kering. Kemenkes RI. Politekhnik Kesehatan.

Kementrian Kesehatan Kendari. Jurusan Gizi.

Nurdiana, W. 2015. Paper Bakso Ubi
Ungu.

http://WinaNurdiana.blogspot.com /EducatoinTechnologyAgroindustr i/paper/bakso/ubi/ungu/23/juli/201 5 diakses pada tanggal 23 Maret 2017

Onggo, T. M. 2006. Perubahan Komposisi Pati dan Gula Dua Jenis Ubi Jalar "Cilembu" Selama Penyimpanan. Jurnal. Universitas Padjajaran. Bandung http://repository. unpad.ac.id diakses pada 10 Juli 2017.

Potter, N.N. and J.H. Hotchkiss. 1995. Food Science (5th ed ). Chapman and Hall. New York

Prayitno.2002. fungsi air kapur dalam pengolahan pangan. www.scribd.com/doc/fungsi-airkapur-dalam-pengolahan-pangan. Diakses pada tanggal 28 Agustus 2017

Rukmana R. 1997. Ubi Jalar. Yogyakarta: Kanisius

Sari. 2014. Pengaruh Jenis Gula Yang Berbeda Tehadap Mutu Permen Jelly Rumput Laut [skripsi]. Fakultas Pertanian. Universitas Islam Indragiri.

Sulisna, R. 2002. Pembuatan Manisan Kering Labu Mie (Curcubita Pepo L) Kajian Konsentrasi Larutan Kapur Dan Lama Pengeringan Terhadap Sifat Fisik, Kimia Dan Organoleptik. Skripsi. Jurusan THP. Fakultas teknologi pertanian. Universitas Brawijaya. Malang.

Standar Nasional Indonesia. 0131440. 2005. Gula Kristal Putih. Jakatra: Badan Standarisasi

Setyaningsih, D.,Anton,A.,Melly,P. 2010. Analisis Sensori Untuk Industri Pangan Dan Agro. IPB Press. Bogor

Suparmo dan Sudarmanto. 1991. Proses Pengolahan Tebu. PAU Pangan dan Gizi. UGM. Yogyakarta. 
Sudarmadji S. Haryono B dan Suhardi. 1997. Prosedur Analisa Untuk Bahan Makanan dan Pertanian. Penerbit Liberty. Yogyakarta

Suryani, S. 2016. Pemanfaatan Limbah Batang Pepaya Dengan Konsentrasi Gula Terhadap Karakteristik Mutu Manisan Kering. [Skripsi]. Fakultas Pertanian. Universitas Islam Indragiri. Tembilahan. Riau.

Wahidah, S. 2016. Budidaya Ubi Jalar Ungu.

http://Sitiwahidah.blogspot.com 7 mei 2016. Bdk barebbo:budidaya ubi ungu

Winarno, F.G. 2008. Kimia Pangan Dan Gizi. Jakarta: PT.Gramedia
Winarti, S. Safora, U. Anggrahini, D. 2008. Ekstraksi dan Stabil Warna Ubi Jalar Ungu (Ipomoea Batatas L) Sebagai Pewarna Alami. Fakultas Teknologi Industri. UPN. Jatim: Surabaya.

Yaningsih, H. Ahmadi, B. H. Mulyani, S. 2012. Studi Karakteristik Gizi Ubi Jalar Ungu (Ipomoea Batatas L) Pada Beberapa Umur Panen. Fakultas Teknologi Pertanian. Universitas Udayana.

Yusuf, M., Rahayuningsih, St.A. dan Pambudi, S. (2003). Pembentukan Varietas Unggul Ubi Jalar Produksi Tinggi yang Memiliki Nilai Gizi dan Komersial Tinggi. Laporan Teknis. Balitkabi. 